Prepared in cooperation with the Gwinnett County Department of Water Resources at $15{ }^{2}$

\title{
Total Suspended Solids Concentrations and Yields for Water-Quality Monitoring Stations in Gwinnett County,
} Georgia, 1996-2009
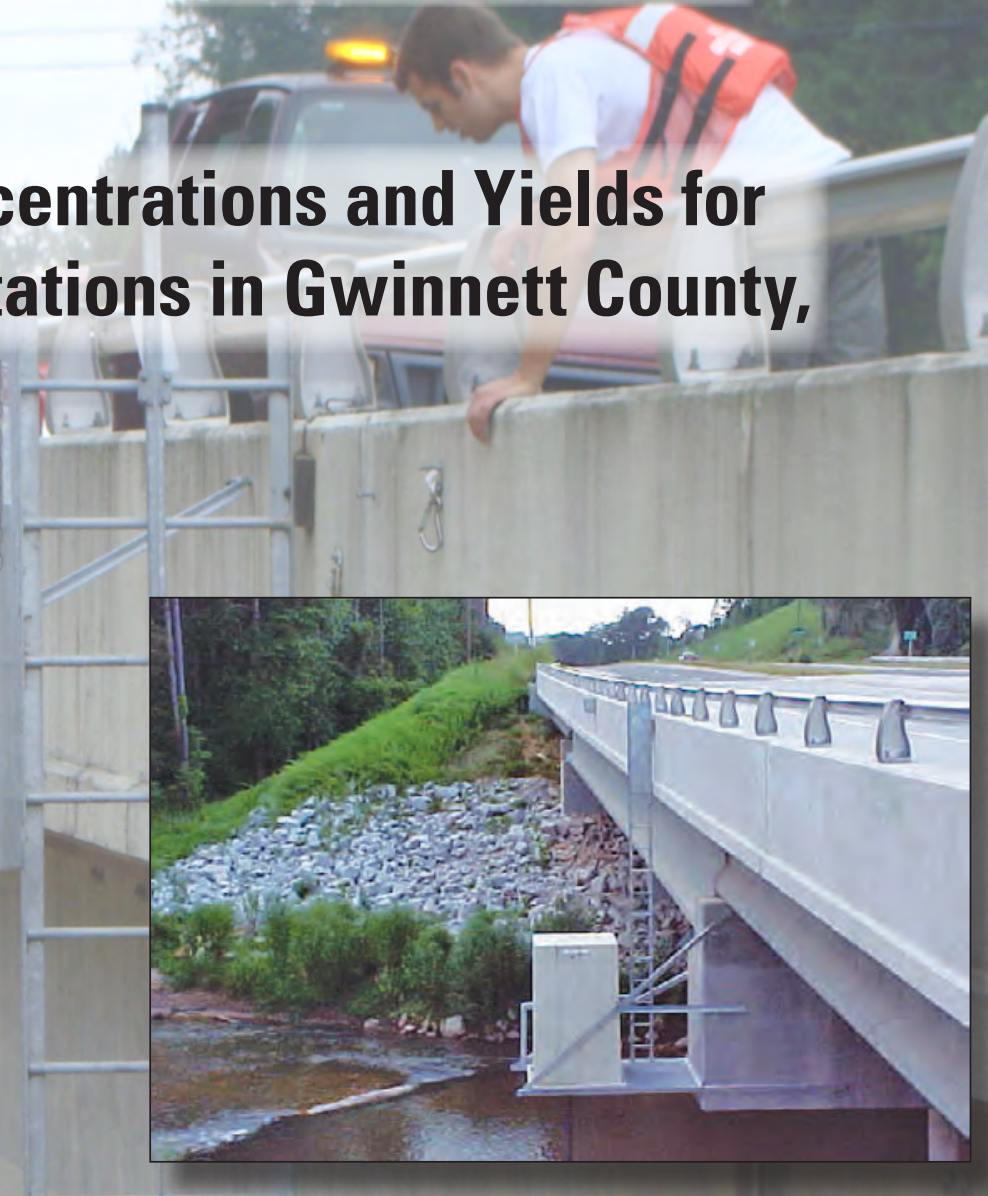

Open-File Report 2013-1145

U.S. Department of the Interior

U.S. Geological Survey 
Front cover: Yellow River at Georgia Highway 124 near Lithonia, Georgia. Inset photograph by Paul D. Ankcorn, USGS; background photograph by Karen W. Stull, USGS.

Back cover: Big Haynes Creek at Lenora Road. Photograph by Stephanie Gillain. 


\section{Total Suspended Solids Concentrations and Yields for Water-Quality Monitoring Stations in Gwinnett County, Georgia, 1996-2009}

By Mark N. Landers

Prepared in cooperation with the Gwinnett County Department of Water Resources

Open-File Report 2013-1145 


\title{
U.S. Department of the Interior SALLY JEWELL, Secretary
}

\section{U.S. Geological Survey Suzette M. Kimball, Acting Director}

\author{
U.S. Geological Survey, Reston, Virginia: 2013
}

For more information on the USGS - the Federal source for science about the Earth, its natural and living resources, natural hazards, and the environment, visit http://WwW.usgs.gov or call 1-888-ASK-USGS.

For an overview of USGS information products, including maps, imagery, and publications, visit http://WwW.usgs.gov/pubprod

To order this and other USGS information products, visit http://store.usgs.gov

Any use of trade, firm, or product names is for descriptive purposes only and does not imply endorsement by the U.S. Government.

Although this information product, for the most part, is in the public domain, it also may contain copyrighted materials as noted in the text. Permission to reproduce copyrighted items must be secured from the copyright owner.

Suggested citation:

Landers, M.N., 2013, Total suspended solids concentrations and yields for water-quality monitoring stations in Gwinnett County, Georgia, 1996-2009: U.S. Geological Survey Open-File Report 2013-1145, 10 p., available online at http://pubs.usgs.gov/of/2013/1145/. 


\section{Contents}

Abstract
Introduction
Total Suspended Solids Concentrations
Quality-Control Samples
Total Suspended Solids and Suspended Sediment Concentration
Total Suspended Solids Yields
$\quad$ Calibration Dataset
Accuracy of Estimated Yields
Summary.
References.

\section{Figures}

1. Map showing location of study area, watershed boundaries, and monitoring stations in Gwinnett County, Georgia

2. Graph showing total suspended solids concentrations of samples taken concurrently at fixed-point sample intake and across the stream cross section for the 14 study watersheds in Gwinnett County, Georgia.

3. Graph showing total suspended solids concentration and suspended sediment concentration for 380 storm samples from 14 watersheds in Gwinnett County, Georgia, 1996-2009.

4. Graph showing concentration of total suspended solids and turbidity and discharge for samples collected in Suwanee Creek at Suwanee, Georgia, 1996-2009.

5. Graph showing cumulative observed and estimated total suspended solids load for 67 storm samples collected for Suwanee Creek at Suwanee, Georgia, 1996-2009

\section{Tables}

1. Water-quality monitoring stations, Gwinnett County, Georgia ............................................

2. Statistical summary of total suspended solids concentration for water-quality monitoring stations in Gwinnett County, Georgia

3. Characteristics of regression models used to estimate concentration of total suspended solids for water-quality monitoring stations in Gwinnett County, Georgia.

4. Total suspended solids annual yields, in pounds per acre per year, for water-quality monitoring stations in Gwinnett County, Georgia 
Conversion Factors and Datum

\begin{tabular}{|c|c|c|}
\hline Multiply & By & To obtain \\
\hline \multicolumn{3}{|c|}{ Length } \\
\hline inch & 2.54 & centimeter $(\mathrm{cm})$ \\
\hline inch & 25.4 & millimeter (mm) \\
\hline foot $(\mathrm{ft})$ & 0.3048 & meter $(\mathrm{m})$ \\
\hline mile (mi) & 1.609 & kilometer (km) \\
\hline \multicolumn{3}{|c|}{ Area } \\
\hline square mile $\left(\mathrm{mi}^{2}\right)$ & 2.590 & square kilometer $\left(\mathrm{km}^{2}\right)$ \\
\hline acre & 4,047 & square meter \\
\hline \multicolumn{3}{|c|}{ Volume } \\
\hline million gallons (Mgal) & 3,785 & cubic meter $\left(\mathrm{m}^{3}\right)$ \\
\hline \multicolumn{3}{|c|}{ Flow/transport rate } \\
\hline cubic foot per second & 0.02832 & cubic meter per second \\
\hline million gallons per day (Mgal/d) & 0.04381 & cubic meter per second $\left(\mathrm{m}^{3} / \mathrm{s}\right)$ \\
\hline pound per acre & 1.121 & kilogram per hectare \\
\hline \multicolumn{3}{|c|}{ Mass } \\
\hline pound & 0.4536 & kilogram $(\mathrm{kg})$ \\
\hline \multicolumn{3}{|c|}{ Constituent yield } \\
\hline $\begin{array}{l}\text { pounds per acre per year } \\
{[(\mathrm{lb} / \mathrm{acre}) / \mathrm{yr}]}\end{array}$ & 1.121 & $\begin{array}{l}\text { kilograms per hectare per year } \\
{[(\mathrm{kg} / \mathrm{ha}) / \mathrm{yr}]}\end{array}$ \\
\hline
\end{tabular}

Horizontal coordinate information is referenced to the North American Datum of 1983 (NAD 83).

Concentrations of chemical constituents in water are given in milligrams per liter.

\section{Acknowledgments}

The author wishes to thank personnel of the Gwinnett County Department of Water Resources for their long-term commitment to improved data and understanding of streamwater quality in their watersheds. This report is possible because of the field data collection and analysis expertise of the U.S. Geological Survey, Gwinnett Project personnel: Paul Ankcorn, Jon Evans, John Joiner, Brandon Reyes, Jolene Robichaux, and Karen Stull. 


\title{
Total Suspended Solids Concentrations and Yields for Water-Quality Monitoring Stations in Gwinnett County, Georgia, 1996-2009
}

\author{
By Mark N. Landers
}

\begin{abstract}
The U.S. Geological Survey, in cooperation with the Gwinnett County Department of Water Resources, established a water-quality monitoring program during late 1996 to collect comprehensive, consistent, high-quality data for use by watershed managers. As of 2009, continuous streamflow and water-quality data as well as discrete water-quality samples were being collected for 14 watershed monitoring stations in Gwinnett County.

This report provides statistical summaries of total suspended solids (TSS) concentrations for 730 stormflow and 710 base-flow water-quality samples collected between 1996 and 2009 for 14 watershed monitoring stations in Gwinnett County. Annual yields of TSS were estimated for each of the 14 watersheds using methods described in previous studies. TSS yield was estimated using linear, ordinary least-squares regression of TSS and explanatory variables of discharge, turbidity, season, date, and flow condition. The error of prediction for estimated yields ranged from 1 to 42 percent for the stations in this report; however, the actual overall uncertainty of the estimated yields cannot be less than that of the observed yields ( \pm 15 to 20 percent). These watershed yields provide a basis for evaluation of how watershed characteristics, climate, and watershed management practices affect suspended sediment yield.
\end{abstract}

\section{Introduction}

The U.S. Geological Survey (USGS), in cooperation with Gwinnett County Department of Water Resources, established a water-quality monitoring program during late 1996 to collect comprehensive, consistent, high-quality data for use by watershed managers. Water-quality sample collection began during 1996, and by 2001, 12 watersheds were being monitored continuously for streamflow, precipitation, temperature, specific conductance, and turbidity, with hydrograph-based sampling of three storm events and three base-flow periods every 6 months. Two watersheds were added to the study during 2006-2007 (fig. 1; table 1). This report summarizes total suspended solids (TSS) data collected at these sites through the 2009 water year (October 1, 2008, to September 30, 2009).

The overall purpose of USGS water-quality monitoring in Gwinnett County is to provide a long-term record of comprehensive and consistent hydrologic and water-quality data that can be used by county and State watershed managers and engineers to evaluate effectiveness of water-management practices on streamwater quality in the county. This water-quality monitoring program provides measurements of stream hydrology and constituent concentrations and yields. The methods used follow USGS protocols and quality-assurance procedures and are consistent between watersheds and over time.

Leading causes of stream impairment in the United States are sediment-associated constituents, such as bacteria, excessive sediment, nutrients, and trace metals (U.S. Environmental Protection Agency, 2002). Sediment concentrations and yields change with natural and human-influenced watershed characteristics (Landers and others, 2007). Annual yield of total suspended sediment is a primary performance criterion in Gwinnett County's Watershed Protection Plan, which is tied to its water-use permits (Gwinnett County Department of Water Resources, 2000).

Specific goals of the long-term monitoring program include

- Monitoring water-quantity and quality status in real time;

- Monitoring long-term and seasonal water-quantity and quality trends;

- Providing flood-warning data for emergency managers and the public;

- Providing data to water managers to evaluate and meet regulatory monitoring requirements of permits for water-supply withdrawals, wastewater discharges, stormwater, source-water watersheds, and total maximum daily load studies; and

- Providing data for computation of constituent loads and yields. 


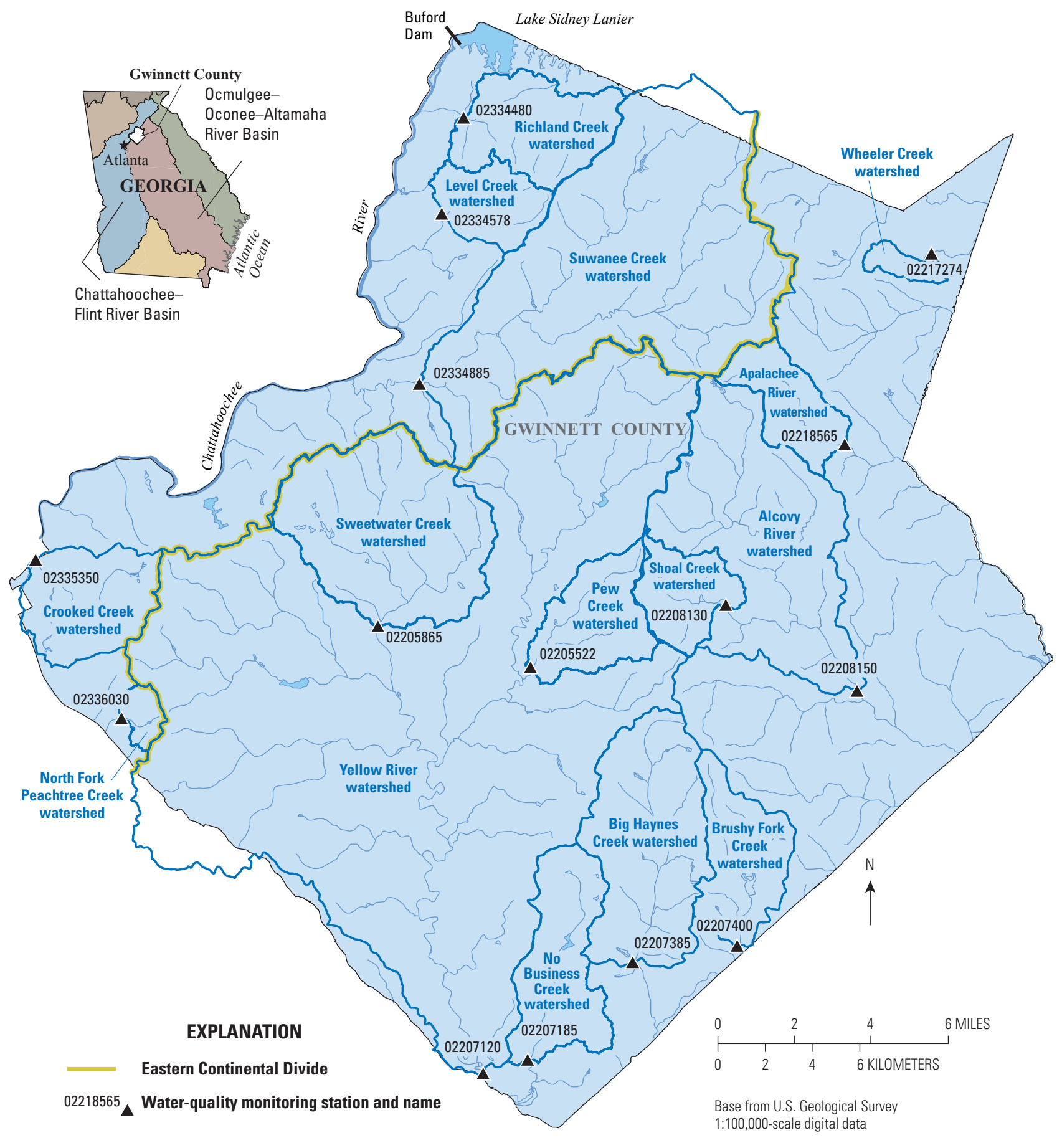

Figure 1. Location of study area, watershed boundaries, and monitoring stations in Gwinnett County, Georgia. 
Table 1. Water-quality monitoring stations, Gwinnett County, Georgia.

[USGS, U.S. Geological Survey]

\begin{tabular}{llcc}
\hline $\begin{array}{c}\text { USGS station } \\
\text { number }\end{array}$ & \multicolumn{1}{c}{ Station name } & $\begin{array}{c}\text { Year } \\
\text { established }\end{array}$ & $\begin{array}{c}\text { Drainage area, } \\
\text { in square miles }\end{array}$ \\
\hline 02205522 & Pew Creek at Patterson Road, near Lawrenceville, GA & 2006 & 7 \\
02207120 & Yellow River at GA 124, near Lithonia, GA & 1998 & 162 \\
02207185 & No Business Creek at Lee Road, below Snellville, GA & 2001 & 10.1 \\
02207385 & Big Haynes Creek at Lenora Road, near Snellville, GA & 1998 & 17.3 \\
02207400 & Brushy Fork Creek at Beaver Road, near Loganville, GA & 1998 & 8.15 \\
02208130 & Shoal Creek at Paper Mill Road, near Lawrenceville, GA & 2006 & 3.9 \\
02208150 & Alcovy River at New Hope Road, near Grayson, GA & 1998 & 30.8 \\
02217274 & Wheeler Creek at Bill Cheek Road, near Auburn, GA & 2001 & 1.31 \\
02218565 & Apalachee River at Fence Road, near Dacula, GA & 2001 & 5.68 \\
02334480 & Richland Creek at Suwanee Dam Road, near Buford, GA & 2001 & 9.34 \\
02334578 & Level Creek at Suwanee Dam Road, near Suwanee, GA & 2001 & 5.02 \\
02334885 & Suwanee Creek at Suwanee, GA & 1998 & 47 \\
02335350 & Crooked Creek near Norcross, GA & 1998 & 8.89 \\
02336030 & North Fork Peachtree Creek at Graves Road, near Doraville, GA & 2001 & 1.42 \\
\hline
\end{tabular}

A previous report (Landers and others, 2007) describes monitoring methods, physiographic and climatic setting, watershed characteristics, analytical methods, water-quality concentrations and yields, trends in water quality, and watershed effects on hydrology and water quality for watersheds in Gwinnett County. Data and analytical results in Landers and others (2007) are limited to the six watersheds that were monitored beginning in 1996 through the 2003 water year.
This report provides statistical summaries of TSS sample concentrations and annual yields of TSS for each of the 14 watersheds monitored through the 2009 water year. The monitoring methods and analytical approach are the same as those described by Landers and others (2007). This report updates the quality-assurance summary for TSS and describes minor changes to the analytical methods used by Landers and others (2007). This report does not include interpretive analysis of watershed effects on water quantity and water quality. 


\section{Total Suspended Solids Concentrations}

Water-quality samples were collected during a wide range of hydrologic conditions. Methods of data collection are described in Landers and others (2007) and follow procedures documented in published manuals, techniques, and quality-assurance plans (Rantz, 1982a, b; Wilde and others, 1998; Wagner and others, 2000; Gotvald and Stamey, 2005). Quality-control samples also were collected to verify that samples were representative and uncontaminated. Concentration data were combined with streamflow and turbidity data to compute annual TSS yields.

Between 1996 and 2009, TSS analyses were conducted for about 730 stormflow and 710 base-flow water-quality samples collected from the 14 watershed monitoring stations listed in table 1. Analytical results for individual samples have been provided to the Gwinnett County Department of Water Resources and are available at http://nwis.waterdata.usgs. gov/ga/nwis/qwdata. Users also can access these data through the project Web site at http://ga2.er.usgs.gov/urban/gwinnett, which provides other supporting data. A statistical summary of TSS concentrations for each station are listed in table 2 . These statistical summaries represent stormflow and base-flow samples collected from 1996 to 2009. Quality-assurance samples are not included in these summaries.

\section{Quality-Control Samples}

The USGS develops quality-assurance and qualitycontrol procedures to ensure that water-quality data meet standards and accurately represent stream conditions. These procedures are documented in published manuals, techniques, and quality-assurance plans (Rantz, 1982a, b; Wilde and others, 1998; Wagner and others, 2000; Gotvald and Stamey, 2005). Because fixed-point samplers collect samples from a single point in the stream cross section, concurrent replicate samples must be collected to ensure that the point sample is representative of the entire cross section. Two concurrent samples are taken - one from the stream cross section using depth integrated, equal-width-increment (EWI) methods as described in Wilde and others (1998), and another from a point in the stream cross section using a fixed-point sampler. Both samples are independently processed and analyzed.

Forty-four pairs of concurrent samples were collected from 1996 to 2009 in all of the monitored watersheds and were analyzed for concentrations of TSS (fig. 2). An equal-value line has been added to figure 2 to show where concentrations from the concurrent samples would be equal. Of the 44 pairs of concurrent TSS samples, 73 percent of the fixed-point sampler concentrations were within 10 percent of the concurrent EWI concentrations, and 90 percent were within 25 percent. The four samples with differences greater than 25 percent are from four different sites.

Equipment-blank quality-control samples are used to check for the presence of constituents from sampling equipment that could contaminate an environmental sample. Equipment contamination may be caused by inefficient cleaning of manual or fixed-point samplers. Of the 52 blank samples collected, 12 percent had constituent concentrations greater than laboratory analytical detection limits. None of these detected concentrations, however, was greater than 4 milligrams per liter, which is well below any stormflow concentrations detected during this study. These quality-control sample results are similar to those from Landers and others (2007).

Table 2. Statistical summary of total suspended solids concentration for water-quality monitoring stations in Gwinnett County, Georgia.

[USGS, U.S. Geological Survey; mg/L, milligrams per liter; \%, quartile percentage of samples that are less than listed concentrations for each station]

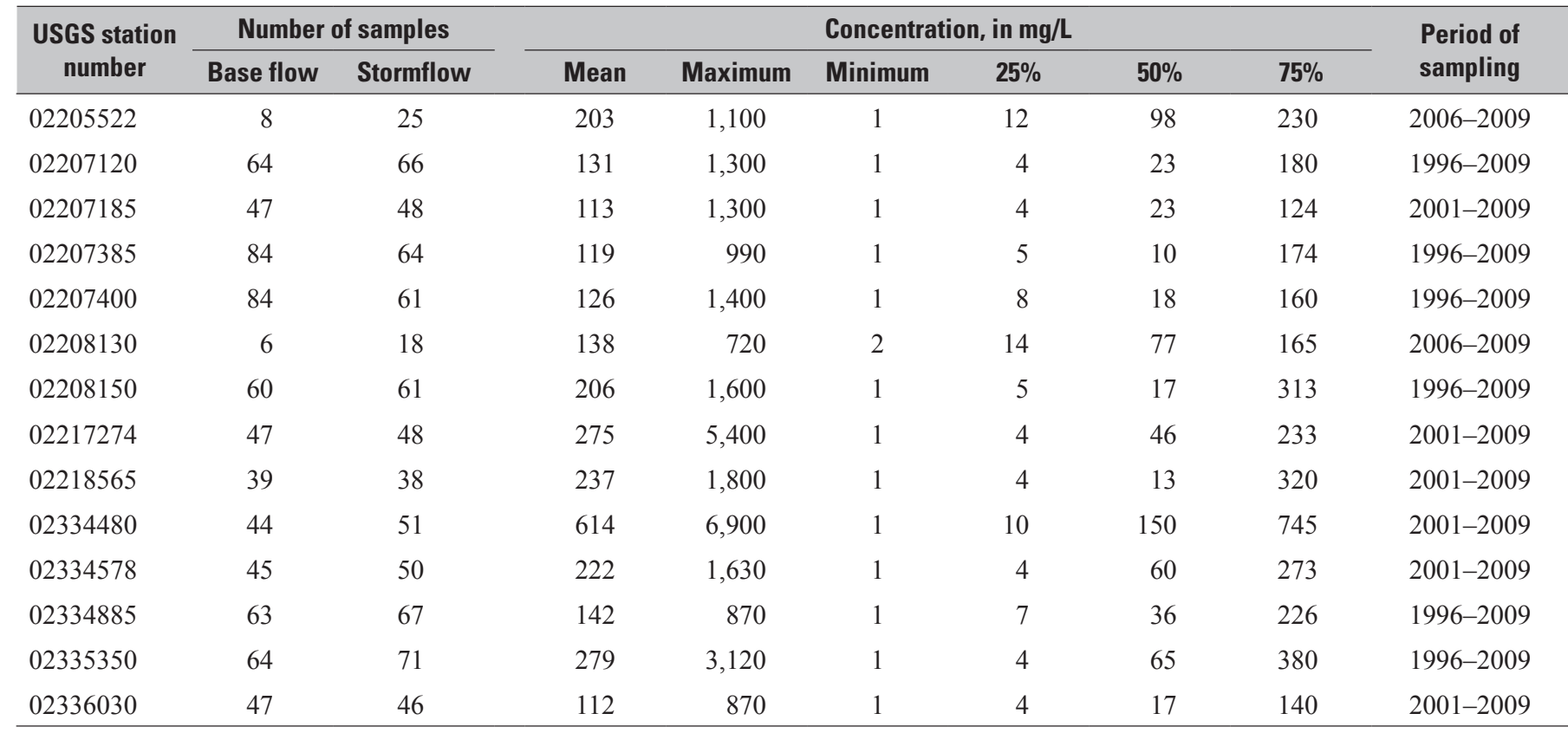




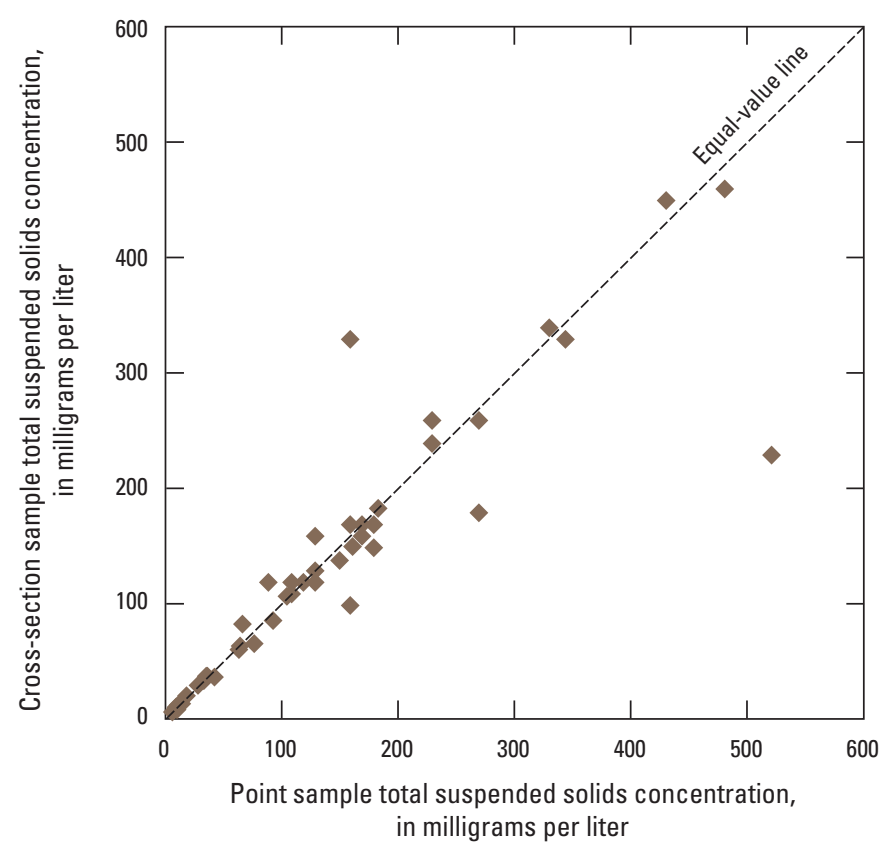

Figure 2. Total suspended solids concentrations of samples taken concurrently at fixed-point sample intake and across the stream cross section for the 14 study watersheds in Gwinnett County, Georgia.

\section{Total Suspended Solids and Suspended Sediment Concentration}

Analyses from previous investigations show that the amount of suspended sediment in streams is greater than indicated by the TSS analysis (Gray and others, 2000; Landers and others, 2007). The amount of suspended material in water is usually determined using laboratory analytical methods for TSS and (or) suspended sediment concentration (SSC). The TSS and SSC analytical methods are slightly different and typically produce different results. The SSC analytical method measures the dry weight of the sediment in an entire sample of a known volume. Laboratory methods for TSS differ among laboratories, but usually involve measuring the dry weight of sediment in a subsample of the available sample volume, rather than in the entire sample. Gray and others (2000) evaluated 3,235 paired SSC and TSS sample analyses and found that this subsampling procedure can undermeasure the total sediment in a sample, particularly when the amount of sand (particles larger than 0.062 millimeter [mm] and less than $2 \mathrm{~mm}$ ) in a sample exceeds about one-quarter of the total sediment mass.
Landers and others (2007) evaluated paired TSS and SSC sample analyses for 160 samples collected between 2001 and 2004. As part of the current study, 380 stormflow samples collected during 2001-2009 in the 14 study watersheds were similarly analyzed. The concentration of TSS typically was less than SSC, as shown in figure 3, in which most of the data plot on the SSC side of the line of equal value. The relation of TSS concentrations and SSC for the 150 samples with less than 25 percent sand has limited scatter; however, the relation for the 230 samples with greater than 25 percent sand content has significant scatter, and TSS concentrations tend to be much less than SSC for these samples, in agreement with the finding of Gray and others (2000). The best fit between TSS and SSC by linear, ordinary least squares regression of all 380 samples (log-transformed) is obtained where SSC is equal to about 1.6 times the TSS with an $\mathrm{R}^{2}$ of 0.76 and a p-value less than 0.0001 . Thus, actual SSC in these streams typically are about 60 percent greater than indicated by TSS values, which is the same result obtained by Landers and others (2007).

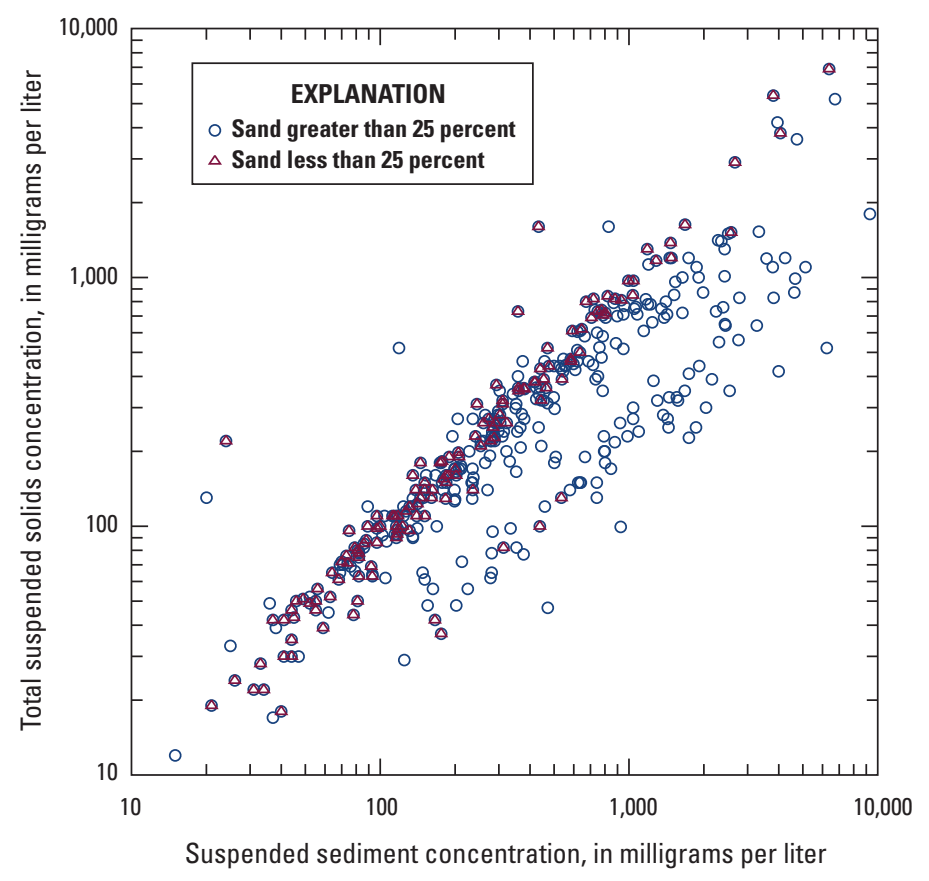

Figure 3. Total suspended solids (TSS) concentration and suspended sediment concentration (SSC) for 380 storm samples from 14 watersheds in Gwinnett County, Georgia, 1996-2009. 


\section{Total Suspended Solids Yields}

The load of a constituent is the mass transport per unit time (for example, tons per year). The yield is simply load per unit area (for example, pounds per acre per year). Yield is obtained by dividing load by watershed area. Yields are loads, normalized for the watershed size. Thus, yields often are used to compare loads between watersheds.

For a sample collected during a storm event, the average concentration and discharge are known, and the observed load is simply the product of concentration (mass per unit volume), discharge (volume per unit time), and the duration of the sample. Although discharge data are available continuously for the monitoring stations of this study, values of concentration are available only for periods when a sample was collected. For unsampled periods, TSS concentration can be estimated using relations of concentration to discharge and (or) turbidity, as illustrated in figure 4 for Suwanee Creek. Estimated load is then taken as the product of estimated TSS concentration, discharge, and duration. The methods used herein follow USGS guidelines (Rasmussen and others, 2009).

Annual TSS yields for the period 1998-2003 and discussion of how land use and climate affect yields are included in Landers and others (2007) for the six watersheds included in that report. The approach used herein differs from that used in Landers and others (2007) in that turbidity was included as an explanatory variable. Turbidity was not used as an explanatory variable in Landers and others (2007) because continuous, consistent turbidity data from in-stream turbidimeters were not available at most of the sites until the 2003 water year.

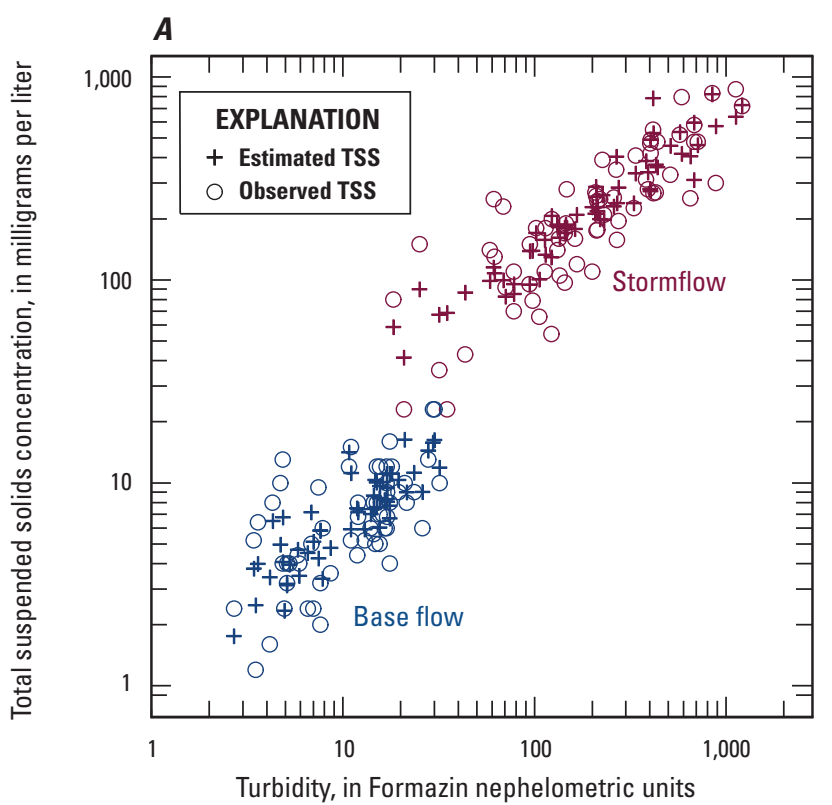

The turbidimeters used in this study have a maximum reporting level of 1,000 Formazin nephelometric units (FNU), and were calibrated to at least that amount for the study period. Turbidity readings higher than this range may be censored and are unreliable. Turbidity values exceeded $1,000 \mathrm{FNU}$ for an average of 11 hours per year at the study sites, and these values were removed from the continuous record for this analysis as recommended in Rasmussen and others (2009).

\section{Calibration Dataset}

The dataset used to calibrate the regression model for computation of annual TSS loads consists of measured streamflow discharge, TSS concentration, and turbidity (in FNU). The date and flow condition (stormflow or base flow) of the sample was also included in the calibration dataset. The sampling design and data collection methods are described in Landers and others (2007). Calibration datasets for each site were evaluated graphically and statistically for correlation, multicollinearity, and outliers. Outliers were removed only if they could be discredited with a high degree of confidence (for example due to noted equipment problems). The number of samples in the calibration dataset ranged from 77 to 148 for 12 of the stations and from 24 to 33 for the two stations that began operation in 2006 (table 2).

The design for this study includes collection of samples in both base-flow and stormflow conditions. These two flow conditions tend to form two populations in the TSS-todischarge relation, as discussed in Landers and others (2007).

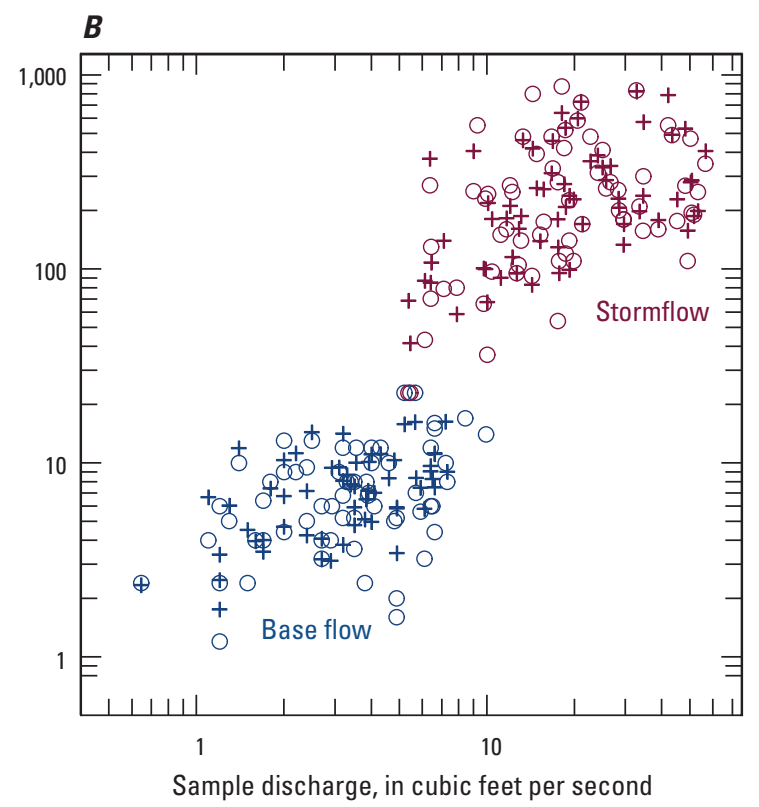

Figure 4. Concentration of total suspended solids (TSS) and (A) turbidity and (B) discharge for samples collected in Suwanee Creek at Suwanee, Georgia, 1996-2009. 
The flow-condition explanatory variable is a binary variable that accounts for whether the sample was collected in a base-flow or stormflow condition. Each time step was classified as stormflow if the turbidity was greater than $20 \mathrm{FNU}$; otherwise it was classified as base flow, based on evaluation of the threshold turbidity for sampled events. For periods with missing turbidity data, a time step was classified as base flow if the streamflow was less than the flow observed in previous streamflow records between 50 to 75 percent of the time for that day of the year.

\section{Regression Model Development}

Linear, ordinary least-squares regression was used to estimate TSS concentration for unsampled periods following methods described in Rasmussen and others (2009). This method was used to select the most accurate estimator of concentration from explanatory variables of discharge, turbidity, season, date, and flow condition for each monitoring station.

An explanatory variable was included in the regression model if it met the following criteria: the coefficient was reasonable in sign and magnitude, model accuracy was improved, it was statistically significant (at a p-value less than or equal to 0.05 for season and time and 0.01 for all other variables), residual analyses indicated adherence to the assumptions of regression, and multicollinearity was not significant. The relations were developed for logarithms of measured TSS and the explanatory variables, as is typical for load estimation. Estimated logarithmic TSS was untransformed (back to linear space) and multiplied by an untransformation bias-correction factor (Duan, 1983; Landers and others, 2007; Rasmussen and others, 2009).

Two regression models were developed for each station - one including and one excluding turbidity as an explanatory variable. This was done so that TSS concentrations could be estimated for those time steps with missing or unreliable turbidity data. Including turbidity as an explanatory variable for estimated TSS concentration improved the regression model accuracy for every station. Multicollinearity between turbidity and discharge, where both were included as explanatory variables, was evaluated using the variance inflation factor and was found to not be a problem for these analyses (Helsel and Hirsch, 1992; Rasmussen and others, 2009). The regression models are summarized in table 3 . The $\mathrm{R}^{2}$ (coefficient of determination) for the regression models ranged from 0.87 to 0.95 , and the regression standard error ranged from 43 to 93 percent. All were statistically significant at a p-value of less than 0.001 .

The time step for each station, listed in table 3 , is based on the typical duration (mean and median) of sampled storm events, as in Landers and others (2007). The explanatory variables were recorded at 15 -minute intervals and averaged over the time-step interval for each station. The TSS load for each time step was then computed from the product of the estimated TSS concentration, streamflow discharge, and time-step duration. The load was summed for each water year and divided by watershed area to obtain annual yield in units of pounds per acre per year for the 14 watersheds of this study (table 4).

\section{Accuracy of Estimated Yields}

Overall accuracy refers to the actual in-stream load or yield compared to estimated load or yield. The accuracy of observed load from measured discharge and TSS concentration for a sampled event depends on errors associated with field sampling and processing and with laboratory analysis. As discussed in Landers and others (2007), the measurement accuracy of loads from measured discharge and TSS concentration is generally on the order of \pm 15 to 20 percent. The accuracy of estimated load or yield from estimated TSS concentration and discharge depends on the accuracy and number of samples in the calibration dataset, the range of measured and observed conditions, uncertainty in the regression estimator (model standard error), and time duration of the estimate. For example, estimated annual yield typically is more accurate than estimated daily yield.

The accuracy of estimated TSS yields was evaluated as the cumulative difference between the observed and estimated yield for the sampled storm events for each station. The cumulative observed and estimated yields are shown in figure 5 for Suwanee Creek for the 67 storm events for which samples were obtained at this site from 1996-2009. Note that figure 5 shows the cumulative load for sampled storms only and does not show the cumulative load for all storms occurring over the period of record. The error of prediction for each site is the cumulative difference between observed and estimated yield as a percentage of the total observed yield. The error of prediction by this method ranged from 1 to 75 percent for the 14 stations in this study; however, the actual overall uncertainty of the estimated yields cannot be less than the measurement uncertainty ( \pm 15 to 20 percent). The standard error of the regression models also is shown in table 3.

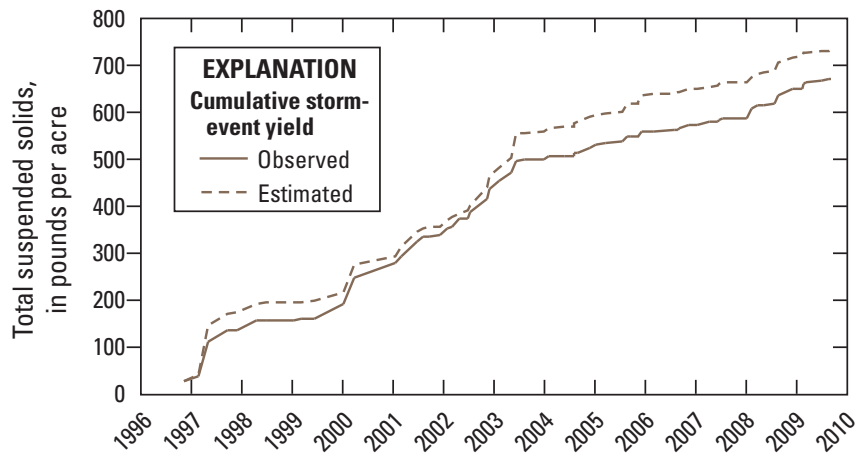

Figure 5. Cumulative observed and estimated total suspended solids load for 67 storm samples collected for Suwanee Creek at Suwanee, Georgia, 1996-2009. 
Table 3. Characteristics of regression models used to estimate concentration of total suspended solids for water-quality monitoring stations in Gwinnett County, Georgia.

[USGS, U.S. Geological Survey]

\begin{tabular}{|c|c|c|c|c|c|c|c|c|c|c|c|}
\hline $\begin{array}{l}\text { USGS } \\
\text { station } \\
\text { number }\end{array}$ & \multicolumn{2}{|c|}{ Number of samples } & $\begin{array}{c}\text { Regression } \\
\mathbf{R}^{2}\end{array}$ & $\begin{array}{l}\text { Regression } \\
\text { model } \\
\text { standard } \\
\text { error, } \\
\text { in percent }\end{array}$ & $\begin{array}{c}\text { 'Error of } \\
\text { prediction, } \\
\text { in percent }\end{array}$ & \multicolumn{6}{|c|}{${ }^{2}$ Explanatory variables } \\
\hline \multirow[t]{2}{*}{02205522} & 8 & 25 & 0.91 & 62 & -7 & - & • & • & - & - & 6 \\
\hline & 8 & 25 & 0.89 & 72 & & • & - & • & • & - & 6 \\
\hline 02207120 & 64 & 66 & 0.93 & 55 & & - & - & - & • & - & 24 \\
\hline \multirow[t]{2}{*}{02207185} & 47 & 48 & 0.92 & 62 & 1 & • & • & • & • & - & 6 \\
\hline & 47 & 48 & 0.89 & 71 & & - & - & - & - & - & 6 \\
\hline 02207385 & 80 & 62 & 0.92 & 60 & -23 & - & • & - & • & - & 12 \\
\hline 02207400 & 84 & 61 & 0.88 & 66 & & • & - & • & • & • & 12 \\
\hline \multirow[t]{2}{*}{02208130} & 6 & 18 & 0.95 & 44 & -4 & - & • & - & - & - & 6 \\
\hline & 6 & 18 & 0.89 & 68 & & - & - & • & - & - & 6 \\
\hline \multirow[t]{2}{*}{02208150} & 58 & 60 & 0.95 & 54 & 38 & - & • & - & - & - & 8 \\
\hline & 60 & 61 & 0.94 & 58 & & - & - & - & - & - & 8 \\
\hline \multirow[t]{2}{*}{02217274} & 47 & 48 & 0.93 & 63 & -26 & - & • & - & - & • & 8 \\
\hline & 47 & 48 & 0.88 & 93 & & - & - & - & - & - & 8 \\
\hline 02218565 & 39 & 38 & 0.95 & 56 & -19 & - & • & - & - & • & 4 \\
\hline \multirow[t]{2}{*}{02334885} & 60 & 66 & 0.95 & 43 & 9 & - & • & - & - & • & 12 \\
\hline & 63 & 67 & 0.92 & 55 & & - & - & - & - & - & 12 \\
\hline \multirow[t]{2}{*}{02335350} & 60 & 67 & 0.95 & 61 & -2 & - & • & - & - & - & 6 \\
\hline & 64 & 71 & 0.93 & 71 & & - & - & - & - & - & 6 \\
\hline \multirow[t]{2}{*}{02336030} & 43 & 46 & 0.89 & 72 & -5 & • & • & - & - & - & 4 \\
\hline & 47 & 46 & 0.87 & 81 & & - & - & - & - & - & 4 \\
\hline
\end{tabular}

${ }^{1}$ The error of prediction for each site is the cumulative difference between observed and estimated yield using both equations as a percentage of the total observed yield. The typical measurement error is less than \pm 20 percent.

${ }^{2}$ Two regression models were developed for each station, one including and one excluding turbidity as an explanatory variable: $\bullet$, explanatory variable included in regession model; - , explanatory variable not included in regession model. 
Table 4. Total suspended solids annual yields, in pounds per acre per year, for water-quality monitoring stations in Gwinnett County, Georgia.

[USGS, U.S. Geological Survey; - , data insufficient to estimate value]

\begin{tabular}{cccccccrrr}
\hline $\begin{array}{c}\text { USGS station } \\
\text { number }\end{array}$ & $\mathbf{2 0 0 2}$ & $\mathbf{2 0 0 3}$ & $\mathbf{2 0 0 4}$ & $\mathbf{2 0 0 5}$ & $\mathbf{2 0 0 6}$ & $\mathbf{2 0 0 7}$ & $\mathbf{2 0 0 8}$ & $\mathbf{2 0 0 9}$ \\
\hline 02205522 & - & - & - & - & 644 & 371 & 265 & 937 \\
$02207120^{1}$ & - & - & 1,040 & 1,950 & 430 & 230 & 223 & 4,770 \\
02207185 & 249 & 1,860 & 460 & 1,140 & 268 & 191 & 75 & 642 \\
$02207385^{1}$ & - & - & 701 & 1,050 & 248 & 150 & 121 & 412 \\
$02207400^{1}$ & - & - & 636 & 1,380 & 208 & 176 & 95 & 386 \\
02208130 & - & - & - & - & - & 238 & 235 & 1,260 \\
$02208150^{1}$ & - & - & 1,650 & 2,370 & 491 & 371 & 281 & 1,870 \\
02217274 & 1,700 & 3,680 & 2,980 & 841 & 635 & 295 & 119 & 424 \\
02218565 & 674 & 3,490 & 2,220 & 1,730 & 554 & 332 & 203 & 971 \\
02334480 & 2,170 & 6,690 & 4,690 & 14,100 & 2,330 & 1,270 & 947 & 2,410 \\
02334578 & 519 & 2,270 & 2,030 & 1,690 & 432 & 287 & 234 & 599 \\
$02334885^{1}$ & - & - & 897 & 1,490 & 381 & 235 & 273 & 854 \\
$02335350^{1}$ & - & - & 2,180 & 3,300 & 1,030 & 834 & 685 & 3,350 \\
02336030 & 721 & 1,190 & 2,460 & 1,260 & 554 & 419 & 325 & 2,330 \\
\hline
\end{tabular}

${ }^{1}$ Yields for 1998-2003 reported in Landers and others, 2007.

\section{Summary}

The U.S. Geological Survey water-quality monitoring program in Gwinnett County provides a long-term record of comprehensive and consistent hydrologic and water-quality data that can be used by watershed managers and engineers to protect and enhance the streams in the county. This report provides statistical summaries of total suspended solids (TSS) concentrations for 730 stormflow and 710 base-flow water-quality samples collected between 1996 and 2009 for 14 watershed monitoring stations in Gwinnett County. Regression models were developed to estimate annual yields of TSS for each of the 14 watersheds through the 2009 water year. The monitoring methods and analytical approach are the same as those described in a previous study. This report does not include interpretive analysis of watershed effects on water quantity and water quality.

Quality-assurance analysis indicated that sample concentrations from the fixed-location pumping samplers are representative of the average cross-section concentrations for all 14 of the study watersheds. Analysis of equipment-blank quality-assurance samples indicated that equipment contamination was not a problem. Concentrations obtained using TSS analytical methods typically underestimate the suspended sediment concentration (SSC) in a water-quality sample. Comparison of 380 paired TSS and SSC samples indicate that SSC is roughly equal to 1.6 times TSS for these watersheds, in agreement with a similar evaluation in a previous study.

TSS loads and yields for each station were estimated using linear, ordinary least-squares regression. The method was used to select the most accurate estimator of TSS from explanatory variables of discharge, turbidity, season, date, and flow condition for each monitoring station. The error of prediction for the estimated yields ranged from 1 to 42 percent for the stations in this report; however, the actual overall uncertainty of the estimated yields cannot be less than that of the observed yields ( \pm 15 to 20 percent). These watershed yields provide a basis for evaluation of how watershed characteristics, climate, and watershed management practices affect suspended sediment yield. 


\section{References}

Duan, Naihua, 1983, Smearing estimate-A nonparametric retransformation method: Journal of the American Statistcal Association, v. 78, no. 383, p. 605-610.

Gotvald, A.J., and Stamey, T.C., 2005, Surface-water qualityassurance plan for the USGS Georgia Water Science Center: U.S. Geological Survey Open-File Report 2005-1246, 45 p., accessed August 4, 2010, at http://pubs.usgs.gov/ of $/ 2005 / 1246 /$.

Gray, J.R., Glysson, G.D., Turcios, L.M., and Schwarz, G.E., 2000, Comparability of suspended-sediment concentration and total suspended solids data: U.S. Geological Survey Water-Resources Investigations Report 00-4191, 14 p., accessed August 4, 2010, at http://pubs.usgs.gov/wri/ wri004191/.

Gwinnett County Department of Water Resources, 2000, Gwinnett County Watershed Protection Plan: Atlanta, GA., CH2MHill, 54 p., accessed August 4, 2010, at http://www. gwinnettcounty.com/static/departments/publicutilities/pdf/ Gwinnett-WPP.pdf.

Helsel, D.R., and Hirsch, R.M., 1992, Statistical methods in water resources: New York, NY, Elsevier Science Publishers, 520 p.

Landers, M.N., Ankcorn, P.D., and McFadden, K.W., 2007, Watershed effects on streamflow quantity and quality in six watersheds of Gwinnett County, Georgia: U.S. Geological Survey Scientific Investigations Report 2007-5132, 62 p.
Rantz, S.E., 1982a, Measurement and computation of streamflow-Volume 1, Measurement of stage and discharge: U.S. Geological Survey Water-Supply Paper 2175, accessed August 4, 2010, at http://pubs.usgs.gov/wsp/wsp2175/.

Rantz, S.E., 1982b, Measurement and computation of streamflow_-Volume 2, Computation of discharge: U.S. Geological Survey Water-Supply Paper 2175, accessed August 4, 2010, at http://pubs.usgs.gov/wsp/wsp2175/.

Rasmussen, P.P., Gray, J.R., Glysson, G.D., and Ziegler, A.C., 2009, Guidelines and procedures for computing time-series suspended-sediment concentrations and loads from instream turbidity-sensor and streamflow data: U.S. Geological Survey Techniques and Methods book 3, chap. C4, 53 p.

U.S. Environmental Protection Agency, 2002, Water quality conditions in the United States: EPA-841-F-02-003, 2 p.

Wagner, R.J., Mattraw, H.C., Ritz, G.F., and Smith, B.A., 2000, Guidelines and standard procedures for continuous water-quality monitors - Site selection, field operation, calibration, record computation, and reporting: U.S. Geological Survey Water-Resources Investigations Report 00-4252, 53 p., accessed August 4, 2010, at http://pubs.usgs.gov/ $\mathrm{tm} / 2006 / \mathrm{tm} 1 \mathrm{D} 3 /$.

Wilde, F.D., Radke, D.B., Gibs, Jacob, and Iwatsubo, R.T, 1998, National field manual for the collection of waterquality data - Handbooks for water-resources investigations: U.S. Geological Survey Techniques of WaterResources Investigations, accessed August 4, 2010, at http://water.usgs.gov/owq/FieldManual/. 
Manuscript approved on June 24, 2013

Edited by Kimberly A. Waltenbaugh Layout by Caryl J. Wipperfurth Science Publishing Network, Raleigh PSC

For more information about this publication, contact: USGS Georgia Water Science Center 1770 Corporate Drive, Suite 500

Norcross, GA 30093

telephone: 678-924-6700

http://ga.water.usgs.gov/ 


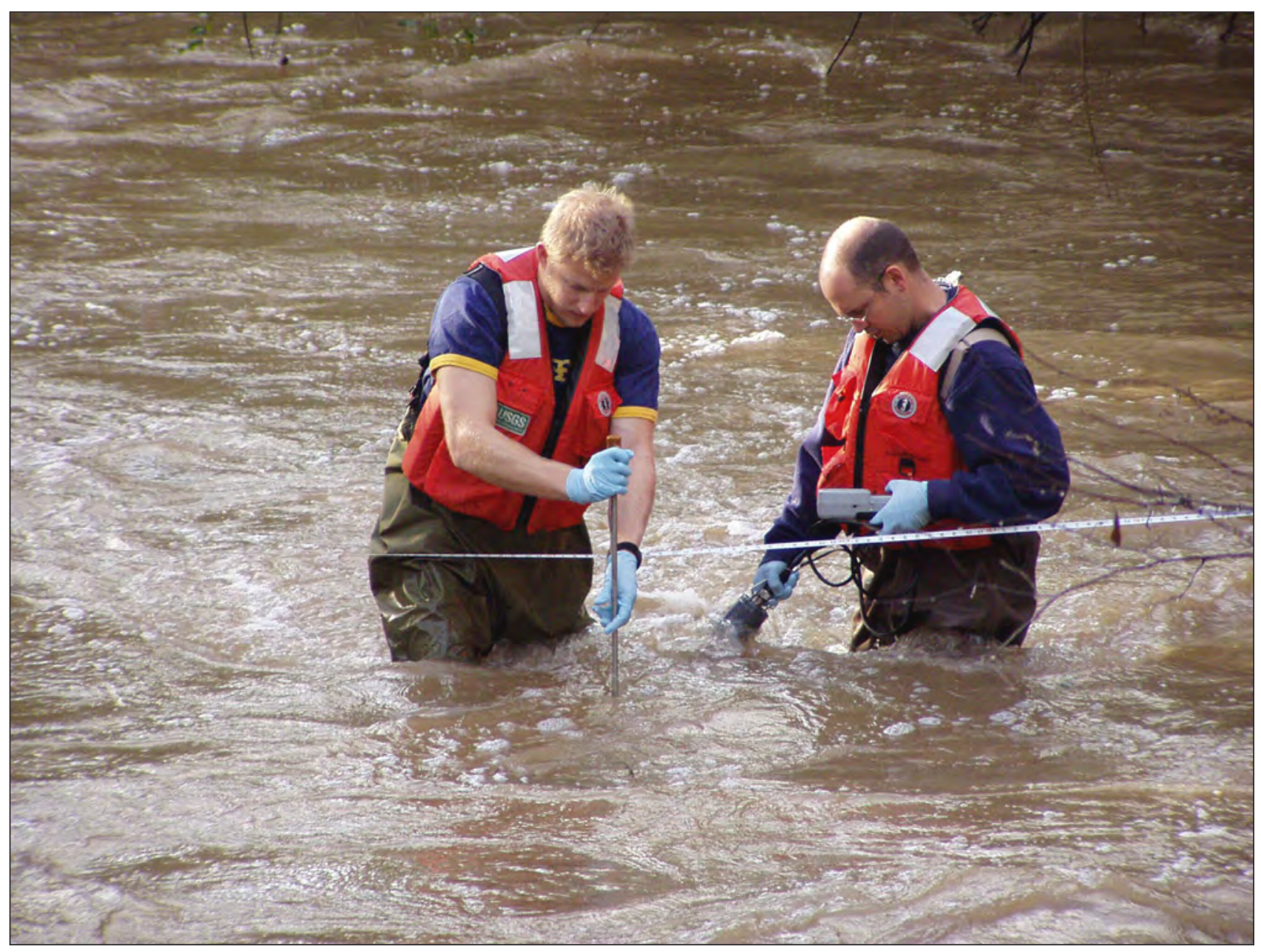

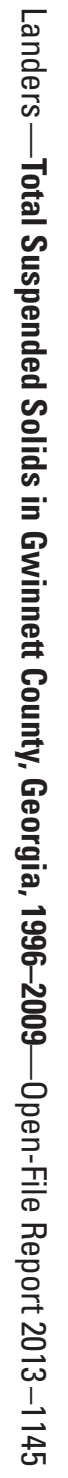

